\title{
High frequency of conjugation versus plasmid segregation of RP1 in epiphytic Pseudomonas syringae populations
}

\author{
Katarina Björklof, Anu Suoniemi, $†$ Kielo Haahtela \\ and Martin Romantschuk
}

Department of Biosciences, Division of General Microbiology, PO Box 41, FIN-00014 University of Helsinki, Finland

\author{
Author for correspondence: Martin Romantschuk. Tel: +3580 70859219. Fax: +358070859262. \\ e-mail: Romantschuk@cc.Helsinki.Fi
}

\begin{abstract}
The maintenance and transfer of the broad host-range plasmid RP1 in epiphytically growing populations of Pseudomonas syringae was monitored in the phyllosphere of bush bean (Phaseolus vulgaris). When foliage was inoculated with plasmid-containing bacteria, the plasmid was lost from the majority of the cells within $2 \mathrm{~d}$ but was stably maintained in $0.8 \%$ of the population. A high frequency of conjugation between added donors and recipients was observed under high humidity conditions. In $1 \mathrm{~d}$, the number of transconjugants rose to $10^{-1}$ of the donors and the proportional level of transconjugants continued to increase until $3 \mathrm{~d}$ after inoculation. Under these conditions the proportion of plasmid-containing bacteria stabilized at about $0.8 \%$ of the total population. The conjugation rate appeared to be in equilibrium with plasmid loss and the slower growth of the plasmid-carrying cells. A factor that influenced the high conjugation frequency observed was the available nutrients provided by the leaf and also, to a lesser extent, the leaf surface itself. Transfer of the plasmid from added donors to indigenous bacteria was also studied, using a donor-specific bacteriophage for counterselection of the donor. Transfer was observed to 10 different species of Gram-negative epiphytically growing bacteria. The bean leaf surface appears to function as a hotspot at least for intraspecific transfer of plasmids in high humidity. The frequency of transfer was higher than in soil or in rhizosphere habitats. This is likely to be the result of an environment that is nutritionally rich in combination with a limited colonizable surface area which permits close contact between the bacterial cells.
\end{abstract}

Keywords: Pseudomonas syringae, leaf surface, conjugation, indigenous bacteria, leachates

\section{INTRODUCTION}

Potential applications of recombinant pseudomonads in agricultural production are increasing. In particular, pseudomonads have been proposed as biological control agents of disease-causing micro-organisms, insects and nematodes in addition to preventing frost damage (Lindow, 1992). However, before large-scale release of recombinant strains into the environment is envisaged,

†Present address: Institute for Biotechnology, University of Helsinki, Helsinki, Finland.

Abbreviation: MIS, Microbial Identification Systems. questions related to survival and possible effects on indigenous organisms in the relevant habitat must be addressed (Tiedje et al., 1989). In some of the proposed applications, the site of action is the leaf surface, which has many distinctive features when compared to other habitats. The prevalent conditions include high and rapid variations in humidity and temperature as well as higher exposure to UV radiation (Lindow, 1991). As the diurnal and seasonal changes are large, the microbial populations are likely to fluctuate more than in other habitats. Many of the bacteria are present only transiently on the leaves due to the high immigration and emigration levels (Hirano \& Upper, 1991), and bacteria are also unevenly distributed (Leben, 1988). The true epiphytes are adapted for survival in conditions where bacteria typical of other habitats 
decline rapidly. The nutrient status is generally limited on the leaf surface (Andrews, 1992) and the nutrients present diffuse out onto the surface. The leachates contain essential minerals as well as sugars, organic acids, amino acids and vitamins (Tukey, 1970). Variations in light intensity has also been shown to directly affect leaching of carbohydrates (Tukey et al., 1957).

Gene transfer is one possible means by which introduced strains may interact with indigenous bacteria. The most readily monitored mode of transfer of genetic material is conjugation of self-transmissible plasmids. It has been estimated that about $18 \%$ of all epiphytes isolated from different geographical regions contain plasmids, and also phytopathogenic strains such as those of Erwinia, Klebsiella and Xanthomonas, and Pseudomonas syringae pv. tomato contain conjugative plasmids (Bender \& Cooksey, 1986; Powell et al., 1993). High frequencies of conjugation between added donors and recipients on the leaf surface and in the leaf tissue have been reported (Lacy \& Leary, 1975; Lacy et al., 1984; Manceau et al., 1986).

In most of the other natural environments studied, conjugal transfer frequencies have been low, but increase has followed nutrient amendments (Top et al., 1990; Klingmüller, 1991) or been due to the presence of roots when considering soil habitats (van Elsas et al., 1988; Lilley et al., 1994). Plasmid transfer to indigenous bacteria was shown to occur in activated sludge and soil, after addition of donors with a poor survival capacity (McClure et al., 1990; Henschke \& Schmidt, 1990). By using an auxotrophic Escherichia coli donor strain in nutrientamended sea water, Sörensen (1993) showed transfer of the plasmid RP4 to P. fuorescens, P. cepacia, and Aeromonas and Enterobacter strains. Smit et al. (1991) used a donorspecific phage as a selection against the donor bacteria for detection of RP4 transfer to Pseudomonas, Xantbomonas, Comamonas, Enterobacter and Alcaligenes strains in soil.

In this work, we studied the spread and maintenance of a self-transmissible plasmid in an epiphytic bacterial population. The transfer of the broad host-range IncP plasmid RP1, from an added $P$. syringae strain to added intraspecific recipient bacteria and to the resident epiphytic bacterial flora was shown to occur readily in the absence of selection pressure for the plasmid.

\section{METHODS}

Bacterial strains, growth media and plant material. Pseudomonas strains (Table 1) used in conjugations and inoculations as well as indigenous bacteria isolated from plant surfaces (Tables 1 and 2), were grown in Kings B (KB) broth (King et al., 1954) overnight at $28^{\circ} \mathrm{C}$ or at room temperature on a shaker. $\mathrm{KB}$ agar plates used for enumeration of bacteria from leaf washes were incubated for $2-5 \mathrm{~d}$. The E. coli strains $\mathrm{K} 12$ (used as donor), $\mathrm{DH} 5 \alpha$ (used as recipient) and $\mathrm{HB} 101 \mathrm{~N}$ (used in phage testing) were similarly grown in Luria Bertani (LB) broth (Miller, 1972) at $37^{\circ} \mathrm{C}$ overnight. Antibiotics were added to KB and LB media when required at the following final concentrations $\left(\mu \mathrm{g} \mathrm{ml}^{-1}\right)$ : ampicillin (Ap), 150; kanamycin $(\mathrm{Km}), 25$; tetracycline (Tc), 10; spectinomycin (Sp), 100; rifampicin (Rif), 75 ; nalidixic acid (Nal), 40. For measurements of bacterial growth, a Klett-Summerson colorimeter with a $520-580 \mathrm{~nm}$ filter was used.

A derivative of the $\mathrm{Rif}^{\mathrm{R}}$, non-pathogenic leaf colonizer $P$. syringae Cit7 was used as the donor strain in all experiments (Table 1). The derivate used was constructed by introducing a mini-Tn 5 spectinomycin unit to the chromosome of the strain by the method of de Lorenzo et al. (1990). The plasmid RP1, identical to RP4 (Burkardt et al., 1979), was introduced to Cit7Sp by conjugation from E. coli K12(RP1). This $60 \mathrm{~kb}$ selftransmissible plasmid confers resistance to $\mathrm{Ap}, \mathrm{Km}$ and $\mathrm{Tc}$ (Grinsted et al., 1972), and sensitivity to the phage PRD1 (Olsen \& Shipley, 1972) The resulting strain, Cit7Sp(RP1), was used as the plasmid donor in all experiments. The donor was isolated from leaf washes with $\mathrm{R}$ if-Sp-Km selection.

All introduced recipient strains used were $\mathrm{Nal}^{\mathrm{R}}$ (Table 1 ), as $\mathrm{Nal}$ used in the plates inhibits DNA replication and thus conjugation from $\mathrm{Nal}^{\mathrm{S}}$ cells (Smit \& van Elsas, 1990). A Nal ${ }^{\mathrm{R}}$ derivative of the $x y l E$ gene-carrying strain $P$. syringae Cit $7 x y l E$ (Lindow et al., 1992) was used as the isogenic recipient. This strain (Cit7xylEN) has the ice gene replaced by the catechol-2,3-dioxygenase gene $x y l E$ which enables identification of the strain by formation of the yellow-coloured compound 2-hydroxymuconic semialdehyde when plates are sprayed with catechol (Worsey et al., 1978). Recipients were isolated from leaf washes with Rif-Nal selection and transconjugants with Rif-Nal-Km selection.

Bean plants (Phaseolus vulgaris cultivar Red mexican) were grown in a peat moss-vermiculite mixture until the primary leaves were fully extended (10-14 d) in a growth room at $24 \pm 2{ }^{\circ} \mathrm{C}$ with a photoperiod of $18 \mathrm{~h}$. A halogen light source giving a light intensity of 7000 lux was used. For experiments involving indigenous bacteria, the plants were grown in pots outdoors in a peafield for up to 6 weeks and then transfered to the growth room.

Counterselection of donors. Purified phage for counterselection of donors was obtained as described by Bamford \& Palva (1980). For counterselection of the donor, a host-range mutant with high plating efficiency and clear plaques on Cit7Sp(RP1) was isolated from the $P$. syringae pv. phaseolicolaspecific phage $\phi \mathrm{J} 1$ ( $\mathrm{J}$. Hantula, personal communication) and designated $\phi \mathrm{J} 1.1$. Sensitivity for this phage was tested by pipetting $5 \mu \mathrm{l}$ drops of different dilutions to semi-solid agar plates containing $200 \mu \mathrm{l}$ of various laboratory and indigenous bacteria. Clear plaques after incubation overnight indicated sensitivity to the phage. When selecting for transconjugants of indigenous recipients, counterselection of the donor was achieved by adding phage at $10^{7}$ particles per plate.

Molecular biology techniques. Standard molecular biology techniques (Sambrook et al., 1989) were used for restriction endonuclease digestions, ligations and agarose gel electrophoresis of DNA. To detect plasmid transfer to indigenous bacteria, colony blots were made using nylon membranes (Amersham). For probing of RP1, DNA fragments were separated and labelled with $\left[{ }^{32} \mathrm{P}\right] \mathrm{CTP}$ in low-melting-point agarose. Colony blots were probed using a $7 \mathrm{~kb}$ EcoRI-Bam HI fragment of RP1.

Plate matings. Donor and recipient strains were grown overnight, diluted $1 / 10$ and cultivated for a further $3 \mathrm{~h}$. Cells were pelleted and resuspended in $1 / 5$ vol. of growth medium without antibiotics. Donor and recipient strains were mixed and drops were dried onto agar plates in a laminar hood. Cultures of donor and recipient bacteria were plated separately as controls. The plates were incubated at room temperature overnight. Cells were then resuspended in growth media and plated with appropriate antibiotic selection. 
Table 1. Bacteria used in this study and their sensitivity to the phage $\phi J 1.1$

\begin{tabular}{|c|c|c|}
\hline Bacterium & Origin/reference & $\phi \mathrm{J} 1.1^{\mathrm{e}}$ \\
\hline \multicolumn{3}{|l|}{ Laboratory strains: } \\
\hline \multicolumn{3}{|l|}{ Pseudomonas syringae: } \\
\hline Cit7Sp & Orser et al. (1985)* & +++ \\
\hline Cit $7 X y l E N$ & Lindow et al. (1992) $\dagger$ & +++ \\
\hline pv. phaseolicola HB10Y & Vidaver et al. (1973) & +++ \\
\hline pv. syringae $\mathrm{B} 728 \mathrm{~N}$ & Loper \& Lindow (1987)† & +++ \\
\hline pv. syringae $3556 \mathrm{~N}$ & ICMP†‡ & ++ \\
\hline pv. syringae $\mathrm{J} 900 \mathrm{~N}$ & Mukopadhyay et al. (1990)† & - \\
\hline P. fiuorescens A506N & Wilson \& Lindow (1993)† & - \\
\hline Acinetobacter calcoaceticus ADP-6N & N. Norton, Yale University† & - \\
\hline Escherichia coli: & & - \\
\hline $\mathrm{HB} 101 \mathrm{~N}$ & Sambrook et al. (1989)† & - \\
\hline K12(RP1) & Datta et al. (1971) & ND \\
\hline $\mathrm{DH} 5 \alpha$ & Sambrook et al. (1989) & ND \\
\hline \multicolumn{3}{|l|}{ Epiphytic isolates: } \\
\hline P. cichorii & This study & ++ \\
\hline P. syringae & This study & - \\
\hline P. aureofaciens & This study & - \\
\hline Enterobacter agglomerans & This study & - \\
\hline Sphingobacterium spiritivorum & This study & - \\
\hline Rhodococcus fascians & This study & - \\
\hline Artbrobacter oxydans & This study & - \\
\hline Aureobacterium liquefaciens & This study & - \\
\hline
\end{tabular}

* Reference for the $\mathrm{Sp}^{\mathrm{s}}$ parental strain made $\mathrm{Sp}^{\mathrm{R}}$ in this study.

$\dagger$ Reference for the $\mathrm{Nal}^{\mathrm{S}}$ parental strains made $\mathrm{Nal}^{\mathbf{R}}$ in this study.

$\ddagger$ ICMP, International Collection of Micro-organisms from Plants, Auckland, New Zealand.

ND, not determined.

Table 2. Indigenous bacteria to which RP1 transferred in planta

\begin{tabular}{|c|c|c|c|c|}
\hline \multirow[t]{2}{*}{ Isolate* } & \multicolumn{2}{|c|}{ RP1-specific characteristics } & \multicolumn{2}{|c|}{ No. of isolates } \\
\hline & PRD1 $^{\text {s }}$ & $\begin{array}{c}\text { Restriction } \\
\text { pattern } \dagger\end{array}$ & 1993 & 1994 \\
\hline Alcaligenes faecalis & + & + & & 1 \\
\hline Alcaligenes piecbaudii & + & + & & 2 \\
\hline $\begin{array}{l}\text { Alcaligenes xylosoxydans subsp. } \\
\text { denitrificans }\end{array}$ & + & + & & 10 \\
\hline Enterobacter agglomerans & + & + & & 1 \\
\hline Enterobacter intermedius & - & + & 1 & \\
\hline Pseudomonas fluorescens & + & + & 1 & \\
\hline Pseudomonas putida & + & + & & 1 \\
\hline Spbingobacterium spiritivorum & + & + & 2 & 3 \\
\hline Xanthomonas campestris & + & + & & 3 \\
\hline Xantbomonas maltophilia & + & + & 12 & 4 \\
\hline
\end{tabular}

* Indigenous strains were identified by MIS and API tests. All isolates were identified as plasmid carriers by hybridization with the $7 \mathrm{~kb}$ EcoRI-BamHI fragment of RP1.

$\dagger$ Plasmids isolated and restricted after conjugation to $E$. coli. 
Matings in liquid. Overnight cultures of donor and recipient bacteria, washed twice in $10 \mathrm{mM}$ potassium phosphate buffer ( $\mathrm{pH} 7 \cdot 2$ ), were resuspended to a concentration of $10^{5}$ c.f.u. $\mathrm{ml}^{-1}$ in $250 \mathrm{ml}$ Erlenmeyer flasks containing $25 \mathrm{ml}$ buffer as a shallow layer. To study the effect of surfaces and nutrients, a bean leaf was added. To study the direct effect of nutrients, peptone was added to a concentration of $0 \cdot 1 \%$ to parallel samples. To study the effect of plant leachates, leaf wash was used as medium for conjugation. This was prepared by washing a leaf in buffer for $2 \mathrm{~h}$ and removing the leaf before addition of donors and recipients. Flasks were incubated in the light of the growth room or in the dark without shaking. Each experiment was performed in triplicate. Donors or recipients were incubated alone as controls in similar conditions in duplicate.

Inoculation of plants and quantification of bacteria in planta. The bacteria in $10 \mathrm{mM}$ potassium phosphate buffer $(\mathrm{pH} 7 \cdot 2)$ were mixed immediately before inoculation of the plant foliage. The total inoculum level varied depending on the experiment $\left(10^{5}-10^{8}\right.$ c.f.u. $\left.\mathrm{ml}^{-1}\right)$. Bacteria were inoculated by a brief submersion using method I of Suoniemi et al. (1995). After inoculation, the pots were enclosed in 101 plastic bags (high humidity, $>90 \%$ ). Control plants were treated with sterile buffer. Primary leaves were sampled and bacteria were quantified as described by Suoniemi et al. (1995). Serial dilutions were grown on plates contaning cycloheximide $\left(200 \mu \mathrm{g} \mathrm{ml}^{-1}\right)$ and benomyl $\left(50 \mu \mathrm{g} \mathrm{ml}^{-1}\right)$ to exclude fungal growth. The detection limit was ca. 100 c.f.u. (g leaf fresh wt) ${ }^{\mathbf{- 1}}$. For calculation of the mean from parallel experiments containing some samples with populations below the detection limit, a value of $\log 0.4$ less than the log value of the c.f.u. detection limit was used for the undetectable populations. Mean values of $\log$ [c.f.u. (g leaf fresh $\mathrm{wt})^{-1}$ ] from data from six determinations were compared using Student's $t$ test in SPSS FOR wINDOws.

In studies involving indigenous bacteria, the inoculation of two parallel pots with Cit7Sp(RP1) donor bacteria $\left(10^{8}\right.$ c.f.u. $\left.\mathrm{ml}^{-1}\right)$ was achieved by spraying until run off $(30 \mathrm{ml}$ per pot) and plants were incubated in high humidity.

Isolation and identification of indigenous epiphytes and transconjugants. To isolate indigenous bacteria from the leaf surface, the leaves submerged in $10 \mathrm{ml}$ of $100 \mathrm{mM}$ potassium phosphate buffer $(\mathrm{pH} 7 \cdot 2)$ containing $0 \cdot 1 \%$ peptone were sonicated in an ultrasonic bath for $7 \mathrm{~min}$ (Lindow, 1993). From buffer-inoculated plants, colonies were isolated from KB plates. From donor-inoculated plants, putative transconjugants were picked randomly from KB plates amended with $\mathrm{Km}$, Tc, Ap and $\phi J 1.1$ and the colonies were probed against an RP1 fragment as described above. The presence of RP1 in the indigenous transconjugants was confirmed by testing for sensitivity to the phage PRD1 by cross-streaking bacterial suspensions across PRD1 streaks on plates, and by conjugation to $E$. coli $\mathrm{DH} 5 \alpha$ and visualization of the EcoRI- and PstI- or SpbI-digested plasmid in agarose gel electrophoresis. Comparison of populations for occurrence of conjugation in various conditions was made using the chi-square test.

Indigenous bacteria were identified by standard methods including biochemical characteristics (API20E, API20NE) in combination with the whole-cell fatty acids based on Microbial Identification Systems (MIS-Microbial ID). Whole-cell fatty acids were saponified and methylated according to Miller \& Berger (1985). Fatty acid methyl esters were analysed using a Hewlett Packard 5890A gas chromatograph with a $25 \mathrm{~m} \times$ $0.2 \mathrm{~mm} 5 \%$ methylphenyl silicone fused silica capillary column. The isolates were classified by the MIS library software rSBA (revised version 3.80).

\section{RESULTS}

\section{Characterization of donor and recipient strains}

When the Cit7 derivatives, used in this study as plasmid donors $(\mathrm{Cit} 7 \mathrm{Sp})$ and recipients $(\mathrm{Cit} 7 X y l E N)$, were tested in vitro and in planta for changes in growth rate, no differences were observed as compared to parental strains Cit7 and Cit $7 X y l E$. Plasmid RP1-carrying strains, both donors and transconjugants, grew slower than the plasmid-less strains. They were observed as smaller colonies after the standard incubation period and the count of culturable bacteria was 100-fold lower in overnight liquid cultures with antibiotic selection. Since equal volumes of overnight cultures were used, the initial density of recipients in plate matings and on the leaf surfaces was higher than that of the donor. All the cells in the donor inoculum contained the plasmid at the beginning of in planta experiments (Fig. 1). When strain Cit7Sp(RP1) was grown in the absence of selection, the generation time was estimated at $2 \mathrm{~h} 40 \mathrm{~min}$, and in an overnight culture the number of plasmid-containing bacteria was $60 \%$ of the total. The corresponding generation time for the parental strain Cit7Sp was $2 \mathrm{~h}$ $15 \mathrm{~min}$. Apparently, RP1 both slows the growth of $P$. syringae and is unstable in the absence of plasmidmaintaining selection pressure. A high frequency of RP1 transfer in vitro was achieved in plate matings with strain Cit7Sp as the donor and strain Cit $7 x y l E N$ as the recipient. After a typical overnight mating incubation followed by resuspension of the bacteria, the mean number of transconjugants $\left(3.9 \times 10^{7}\right.$ c.f.u. $\left.\mathrm{ml}^{-1}\right)$ was higher than the number of donors $\left(1.6 \times 10^{6}\right.$ c.f.u. $\left.\mathrm{ml}^{-1}\right)$ when the recipients were in excess $\left(2 \cdot 9 \times 10^{9}\right.$ c.f.u. $\left.\mathrm{ml}^{-1}\right)$. This was apparently a result of multiple consecutive conjugation events where newly formed transconjugants were also likely to function as donors.

\section{Effect of surfaces and nutrients on conjugation in suspension culture}

Two factors that may affect conjugation are the availability of nutrients and the local concentrations of bacteria. The presence of a leaf surface may affect both the nutrient status and the distribution of bacteria in a suspension. To test how this affects the formation of transconjugants, donors and recipients were incubated as a shallow liquid layer in flasks. In unamended buffer, the donor concentration decreased to about $1 / 10$ of the original, whereas the recipient concentration remained constant. No transconjugants were observed after a 2-d incubation period (Table 3). In nutrient-amended flasks, the recipients increased almost 100 -fold, whereas the increase in the donor concentration was smaller. The ratio of transconjugants to total bacteria after $2 \mathrm{~d}$ was $8 \times 10^{-4}$. Addition of a bean leaf to unamended buffer caused no significant growth of either donors or recipients, but transconjugants were still recovered at about $2 \times 10^{-3}$ (Table 3) after a 2-d incubation. Addition of peptone to the leaf-containing mating mixtures did not improve the yield of transconjugants despite growth of donor and recipient cells. The growth of donors and recipients in 


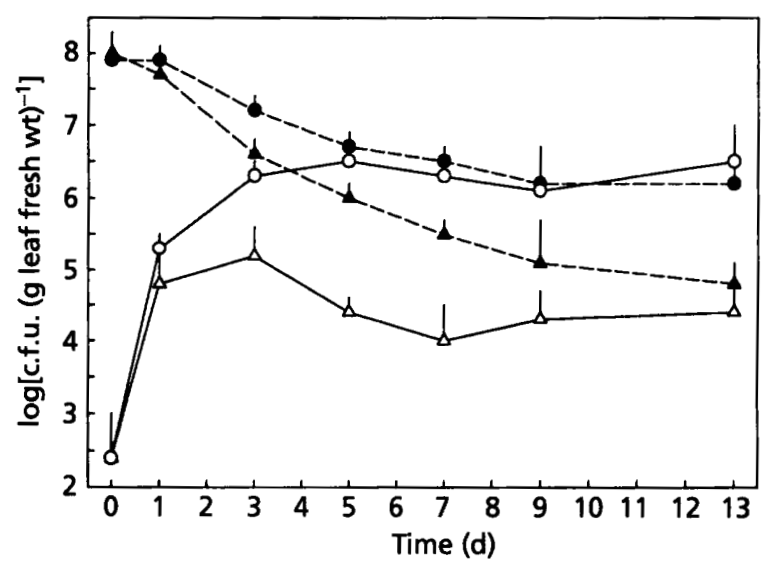

Fig. 1. Plasmid loss from the donor strain $P$. syringae Cit7Sp(RP1) colonizing the leaf surface with high inoculum (A ) or low inoculum $(\triangle, O)$. c.f.u. density measured on plasmid selection (Rif-Sp-Km, $\triangle, \Delta$ ) and on host cell selection (Rif-Sp, $O$, ). The SD of six replicates is indicated by vertical bars.

mating mixtures of leaf washes was similar to growth in mating mixtures with nutrient amendments, indicating that the leaf washing procedure had released nutrients from the leaf in comparable amounts to the peptoneamended buffer. The ratio of transconjugants to total bacteria was, however, slightly lower than in mating mixtures with leaf and nutrient amendments, and considerably lower than mating mixtures incubated with the leaf alone. This indicates that although the nutrients of the leachates mainly contribute to the positive effect, the leaf surface itself stimulates conjugation further.

\section{Plasmid stability in planta}

When Cit7Sp(RP1) donor cells were incubated on leaves in the absence of plasmid-maintaining selection pressure, plasmid-less segregants appeared soon after inoculation. A low inoculum, giving an initial population of 250 c.f.u. (g leaf fresh $w t)^{-1}$, resulted in rapid growth. After $1 \mathrm{~d}$, over $60 \%$ of the bacterial cells were plasmid-less (Fig. 1). An apparent equilibrium with plasmid-containing $\left(\mathrm{Km}^{\mathrm{R}}\right)$ and plasmid-less $\left(\mathrm{Km}^{\mathrm{s}}\right)$ bacteria was achieved when about $0.8 \%$ of the cells carried the plasmid. With an inoculum level of $10^{8}$ c.f.u. (g leaf fresh wt) ${ }^{-1}$, where no net bacterial growth occurred, the plasmid loss was slower and the proportion of plasmid-containing cells had reached $4 \%$ by day 13 (Fig. 1). The final total bacterial numbers in these cases seem to represent the carrying capacity of the leaf under the conditions used. Also, in planta both plasmid segregation and more rapid growth of the plasmid-less segregants seemed to contribute to the rapid increase in numbers of plasmid-less cells. Plasmid loss from $150 \mathrm{Km}^{\mathrm{S}}$ strains was confirmed by colony hybridization.

\section{Intraspecific conjugation in planta}

Using a low bacterial inoculum level, incubation at high humidity levels stimulated rapid growth of the bacteria during the first $24 \mathrm{~h}$, where the generation times were found to be two times longer for the recipient and five times longer for the donor compared to liquid cultures (Fig. 2). Conjugation was also efficient; after the first day the transconjugants represented 1:10 of the donor level. Between the first and the third day after inoculation, the donor population continued to increase, after which it declined to a level of about $10^{4}$ c.f.u. ( $g$ leaf fresh wt) ${ }^{-1}$. The level of transconjugants had surpassed the donor level by the third day. After this, the total level of plasmidcarrying cells declined to about $0.8 \%$ of the plasmid-less recipients after day nine, much in the same way as in the experiment measuring plasmid segregation.

Samples taken from the inoculum mixture, when plated as controls on selective plates, did not generate colonies with transconjugant characteristics, and transconjugants were always absent from time zero samples. We concluded that conjugation did not take place during the inoculation procedure and that the $\mathrm{Nal}$ concentration in the plates was

Table 3. Influence of nutrient and surface addition for appearance of transconjugants in buffer during a 2-d incubation

The inoculation densities were $\log \left(5 \cdot 4 \pm 0 \cdot 2\right.$ c.f.u. $\left.\mathrm{ml}^{-1}\right)$ for the donor and and $\log \left(5 \cdot 7 \pm 0 \cdot 2\right.$ c.f.u. $\left.\mathrm{ml}^{-1}\right)$ for the recipient. Values are expressed as $\log \left(\right.$ c.f.u. $\mathrm{ml}^{-1}$ ) and are the mean values of three replicates $\pm S D$.

\begin{tabular}{|lcccc|}
\hline Addition to buffer & Donors & Recipients & $\begin{array}{c}\text { Trans- } \\
\text { conjugants }\end{array}$ & $\begin{array}{c}\text { Ratio of } \\
\text { trans- } \\
\text { conjugants } \\
\text { to total }\end{array}$ \\
\hline No addition & & & & \\
$0 \cdot 1 \%$ peptone & $4.0 \pm 0.7$ & $5.5 \pm 0.3$ & $<1 *$ & \\
Leaf & $6.0 \pm 0.5$ & $7.6 \pm 0.4$ & $4.5 \pm 0.6$ & $8 \times 10^{-4}$ \\
Leaf +0.1\% peptone & $5.4 \pm 0.1$ & $6.1 \pm 0.6$ & $3.4 \pm 0.4$ & $2 \times 10^{-3}$ \\
Leaf wash & $6.7 \pm 0.5$ & $7.0 \pm 0.3$ & $3.9 \pm 0.6$ & $5 \times 10^{-4}$ \\
& $6.1 \pm 0.1$ & $7.1 \pm 0.2$ & $3.2 \pm 0.1$ & $1 \times 10^{-4}$ \\
\hline
\end{tabular}

* The detection limit was 10 c.f.u. $\mathrm{ml}^{-1}$. 


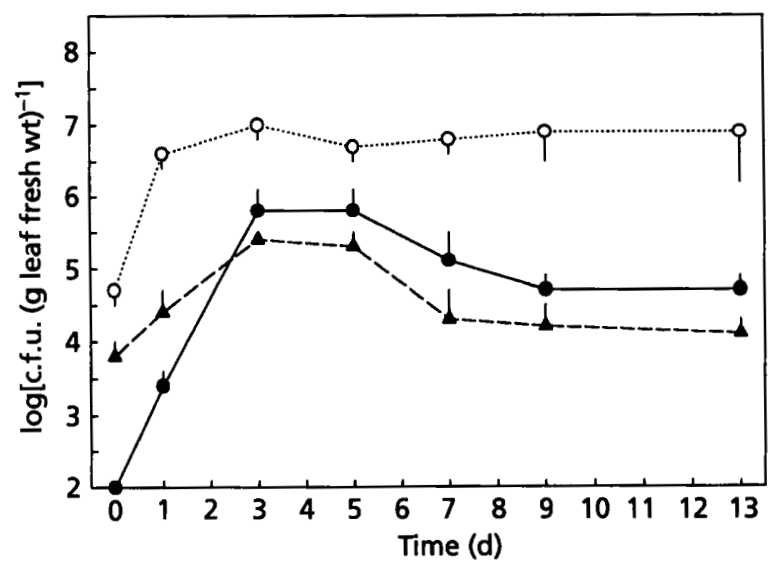

Fig. 2. Presence of $P$. syringae Cit7Sp(RP1) (on donor selection, Rif-Sp-Km, $\mathbf{A}$ ), P. syringae Cit7xylEN (on recipient selection, Rif$\mathrm{Nal}, \mathrm{O})$ and transconjugants (Rif- $\mathrm{Nal}-\mathrm{Km}, 0$ ) on the surface of bean leaves in high humidity $(>90 \%)$ during a 2 -week incubation. The SD of six replicates is indicated by vertical bars.

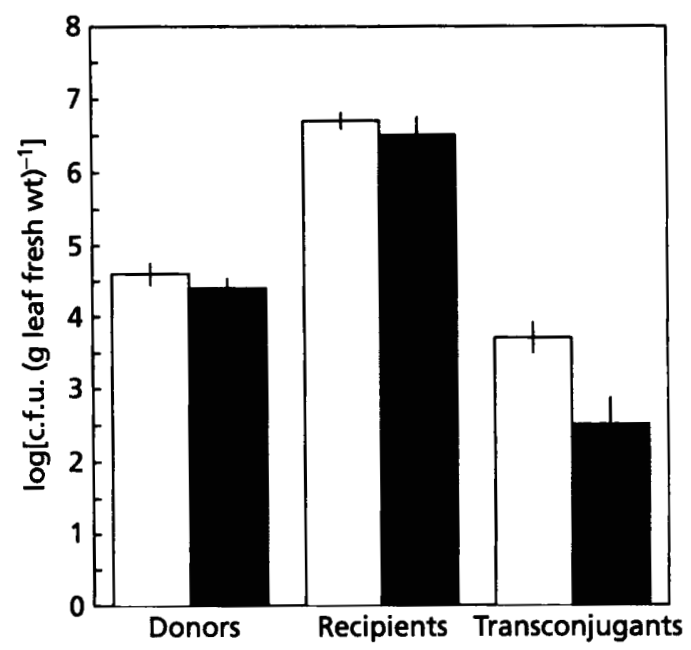

Fig. 3. Comparision of presence of donors $[P$. syringae Cit7Sp(RP1)], recipients ( $P$. syringae Cit7xyIEN) and transconjugants after $1 \mathrm{~d}$ of incubation in the growth room (open bars) or in the dark (shaded bars). The SD of six replicates is indicated by vertical bars.

sufficient to prevent donors from transferring the plasmid after plating.

To test the effect of absence of photosynthesis by the leaves, plants were incubated in darkness in high humidity $1 \mathrm{~d}$ before inoculation of donors and recipients. This was performed to increase the consumption of nutrients by resident bacteria on the leaf surface that were activated by the high humidity, while preventing production of new nutrients through photosynthesis. Before inoculation, the plants were further sprayed with buffer to remove residual nutrients. Inoculated plants were incubated in the growth room or in darkness. Surprisingly after $1 \mathrm{~d}$, no significant differences in the amount of donors and recipients in the two treatments were detected, but the number of trans- conjugants was significantly lower $(P<0.01)$ on plants that had been incubated in the dark (Fig. 3).

\section{Indigenous epiphytes isolated from bean leaves and phage specifity}

To observe plasmid transfer to the indigenous bacterial flora that did not contain any selectable markers, counterselection of the added donor was required. Pre-seeding the plates with the phage $\phi \mathrm{J} 1.1$ reduced the level of sensitive c.f.u. to $2 \times 10^{-4}$ of the plated donors, apparently representing the phage-resistant spontaneous mutants of the host strain. To test the infectivity of the phage used for counterselection in other strains on the phylloplane, eight strains from field-grown beans that differed in colony morphology on $\mathrm{KB}$ plates were isolated and identified by MIS (Table 1). The MIS identification indices were relatively low, indicating that these strains were not closely related to the library strains. The host range of $\phi J 1.1$ was tested on these indigenous strains and on some laboratory strains (Table 1). The phage $\phi \mathrm{J} 1.1$ infected most laboratory $P$. syringae strains tested but not $P$. fluorescens nor the other Gram-negative strains tested. It also infected one of the natural Pseudomonas isolates. Preseeding plates with $\phi \mathrm{J} 1.1 \mathrm{did}$ not affect the total count of culturable bacteria in samples derived from field-grown plants, suggesting that bacteria sensitive to $\phi J 1.1$, although present (Table 1), did not form a large proportion of the bacterial flora of the plants used. The fact that phage counterselection did not affect the total viable count and exhibited a fairly narrow host-range enabled us to use it in monitoring plasmid transfer to indigenous bacteria other than those most closely related to the donor.

\section{Conjugal transfer to indigenous bacteria in planta}

For studying in planta transfer of RP1 to indigenous bacteria, plants were inoculated with $3 \times 10^{6}$ c.f.u. (g leaf fresh wt $)^{-1}$ of donors. The count of the indigenous bacteria increased rapidly from $2 \times 10^{6}$ c.f.u. (g leaf fresh $w t)^{-1}$ to $2 \times 10^{7}$ c.f.u. (g leaf fresh wt) ${ }^{-1}$ when the donor- or buffer-inoculated plants were incubated at high humidity. After $4 \mathrm{~d}$ incubation, the total phage-resistant population on donor-inoculated and buffer-inoculated leaves was identical. The number of donor cells had decreased to $3 \times 10^{5}$ c.f.u. (g leaf fresh wt) ${ }^{-1}$. Also the buffer-inoculated leaves were inhabited by about $4 \times 10^{4}$ c.f.u. (g leaf fresh wt) ${ }^{-1}$ of bacteria with multiple antibiotic resistance $\left(\mathrm{Ap}^{\mathrm{R}} \mathrm{Km}^{\mathbf{R}} \mathrm{Tc}^{\mathbf{R}}\right)$. Potential transconjugants represented only a part of the total c.f.u. resistant to the antibiotics used. During the experiment in the summer 1993, seven of the clones picked from the transconjugant selection on day 0 were identified as donor bacteria. At day four, no donor bacteria were found among the 500 strains studied. During experiments in 1994, no donors were found among the randomly picked potential transconjugants.

The presence of RP1 in the bacteria of a total of 1400 colonies from the Ap-Km-Tc selective plates from five separately treated donor-inoculated plants and 1250 
colonies from the buffer-inoculated leaves was studied. From the donor-inoculated plants, $41 \phi J 1.1^{\mathrm{R}}$, RP1 hybridizing strains were found, of which all but one isolate was also PRD1 ${ }^{\mathrm{S}}$. The presence of RP1 in hybridization-positive clones was confirmed by conjugation to E. coli $\mathrm{DH} 5 \alpha$ and isolation and visualization of the restricted plasmid (Table 2). During the experiment in 1993, three strains from the buffer-sprayed plants hybridized to RP1. All of these strains were identified as Xanthomonas maltophilia. In the later experiments (1994) no RP1-like plasmids were observed in controls that did not contain donors. Since putative transconjugants of $X$. maltophilia were obtained in both experiments, we also conclude that this bacterium had functioned as a recipient in planta.

As a control for plate mating, a buffer-sprayed plant was incubated for $4 \mathrm{~d}$ generating a total population of $10^{6}$ c.f.u. (g leaf fresh wt) ${ }^{-1}$ of which $10 \%$ were resistant to the antibiotics. Dilutions of this leaf wash and of overnight cultures of donors suspended in buffer $\left(10^{9}\right.$ c.f.u. $\left.\mathrm{ml}^{-1}\right)$ were mixed and plated on phage-treated plates. From the $\mathrm{Tc}^{\mathrm{R}} \mathrm{Ap}^{\mathrm{R}} \mathrm{Km}^{\mathrm{R}}$ colonies, 140 were picked and probed against RP1. No RP1-containing strains were found, indicating that transconjugants had not arisen on the phage-seeded plates. The observed control frequency differs significantly from the in planta conjugation frequency $(P<0.05)$. Also, no transconjugants were observed on day 0 in the in planta conjugations, despite the presence of donors and recipients (see above) in the plated samples. We concluded that the transconjugants observed had arisen in planta and not on the plates.

In conclusion, although a proportion of the indigenous transconjugants isolated from the same plant may have been siblings, transfer had occurred in two separate experiments to 10 different bacterial species.

\section{DISCUSSION}

Studies of Lacy et al. (1984) indicated that the leaf surface could act as a hotspot region for conjugation of the plasmid RP1. A high frequency of transfer of RP1 from $P$. syringae pv. glycinea to $P$. syringae pv. phaseolicola in the phylloplane of bean was reported during the first $4 \mathrm{~h}$ after inoculation with an excess of donors (Lacy \& Leary, 1975). Likewise, during the first hours after inoculation, P. syringae pv. syringae and Erwinia berbicola were shown to transfer the same plasmid to E. amylovora on pear blossoms (Lacy et al., 1984). In another plant-associated environment, the rhizosphere, van Elsas et al. (1988) observed a high frequency of conjugation after inoculation with a high number of donor and recipient bacteria.

In this study, a high frequency of conjugation was observed in the phyllosphere at a high humidity level. The transfer frequencies were also high with a low inoculum level where rapid increase of the transconjugant level continued until $3 \mathrm{~d}$ after inoculation. This shows that these bacteria, actively colonizing the leaf surface, can function both as donors and recipients. As the transconjugants increased beyond the donors when recipients were in excess on the leaf surface (Fig. 2), it was evident that the transconjugants formed on the leaf surface could also function as donors. Since plasmid RP1 slows the growth of the $P$. syringae donors and transconjugants, this relative increase in the transconjugant level could not have been due to the increased growth rate of these bacteria. Efficient conjugation also occurred in the leafamended buffer despite the lack of bacterial growth. Presumably, conjugation can also occur between viable, metabolizing but non-dividing cells.

High humidity permitting vigorous bacterial replication and, as shown here, high frequency of conjugation occurs on the phylloplane as a result of dew deposition at night and following rain showers (Lindow, 1991; Juniper, 1991). The leaf surface, exposed to high humidity conditions, was able to support a population density of up to $10^{7}$ c.f.u. (g leaf fresh wt $)^{-1}$. The high humidity provides an aqueous environment for the bacterial cells and causes a leaching of nutrients from the leaf, making these nutrients accessible for the microbes on the surface. Free water on the surface of leaves also enables movement of the bacteria and possibly clustering in certain locations via selective leaf surface attachment as described for $P$. syringae pv. phaseolicola (Romantschuk et al., 1993). It is also likely that photosynthesizing leaves induce chemotactical behaviour in motile $P$. syringae strains, such as Cit7.

RP1 encodes the production of a rigid conjugation pilus that has been reported to require a surface for high frequency of conjugation (Bradley et al., 1980). Addition of a leaf to mating mixtures gave rise to transconjugants in this otherwise nutrient-free environment without permitting extensive bacterial growth (Table 3). This suggests that the microhabitat on the leaf surface supports conjugation by increasing the local concentrations of bacteria and shows that efficient conjugation apparently also took place in conditions where bacterial growth was limited. As conjugation also occurred in leaf washes where the effect of a surface was not present, it appears that both the nutrients supplied by the leaf and the presence of a surface contribute towards efficient conjugation. The positive effect of leachates can also be deduced from the fact that conjugation occurred more efficiently on plants incubated in the light than plants incubated in the dark, although a difference in the chemical composition of the leachates affecting the bacterial behaviour cannot be excluded. Under certain conditions, the phylloplane may form a similar nutrient-rich surface as the rhizoplane, where a sufficiently dense bacterial population can be supported to promote efficient transfer of conjugative plasmids between bacterial cells (van Elsas et al., 1988).

The fact that plasmid segregation also took place where no net bacterial growth occurred (Fig. 1, high inoculum) indicates that the bacteria metabolize and divide also under these conditions, but that the bacteria die or become unculturable at a rate faster than the growth rate. This is always likely to happen when the cell density is higher than the carrying capacity of the habitat. The growth, and thereby also the segregation of the viable bacteria, is probably determined by the nutrients pro- 
duced by the leaf and released from dying bacterial cells under the conditions used. Plasmid segregation and a somewhat slower growth of transconjugants contributes towards a decreasing concentration of plasmids in the epiphytic population, whereas conjugation works in the opposite direction. The fact that both plasmid loss and conjugation measurements resulted in the same relative plasmid content, suggests that these factors are in equilibrium within $10 \mathrm{~d}$ of incubation under the conditions used. Changes in RP4-carrying strains of $X$. campestris making the plasmid more stable have been reported (Tu et al., 1989). Such mutations, which apparently may occur also in $P$. syringae given sufficient time, would be likely to increase the level of plasmid-carrying cells in the population. Whether such mutations have taken place during the in planta incubations reported here is not known. Thus, despite the additional metabolic burden in hosting RP1, such highly conjugative plasmids will not be diluted out from a population even in the absence of selection pressure and therefore behave as selfish, parasitic DNA (Gordon, 1992). Similar observations have been reported for the original TOL plasmid $(117 \mathrm{~kb})$ in P. putida batch cultures (Smets et al., 1993). The presence of a plasmid in a subpopulation may be sufficient to give the population the adaptability provided by a plasmid whose genes are required only in certain conditions. In fact, conjugation might have evolved as a means not only for the dissemination of parasitic plasmids, but also to enable their survival despite a tendency to segregate. In this experimental set-up it was not possible to measure the relative importance of conjugation, segregation and growth retardation for the maintenance of the plasmid at the approximately $1 \%$ level.

It was evident from this study that the indigenous epiphytic bacterial flora of field-grown plants contain a high number of bacteria with multiple resistance markers $\left(\mathrm{Ap}^{\mathrm{R}} \mathrm{Tc}^{\mathrm{R}} \mathrm{Km}^{\mathrm{R}}\right)$. Bacterial resistance to these antibiotics in soils has also been reported at a level of $10^{3}-10^{4}$ c.f.u. ( $\mathrm{g}$ dry wt $)^{-1}$ (Schmidt et al., 1990). Whether or not this is a general feature of the phylloplane is not known.

RP1 was also shown to transfer to indigenous bacteria. The observed selection of 10 bacterial species that functioned as recipients is likely to be an underestimate of the total diversity of recipients. As RP1 replicates in a wide variety of Gram-negative bacteria, it is likely that not all of the indigenous transconjugants grew in the conditions and on the media used. Although most of the isolated transconjugants probably received the plasmid directly from the introduced donor on the leaf surface, some of the transconjugants may have arisen as a result of transfer via an intermediate plasmid host. Furthermore, despite the low effect of phage $\phi \mathrm{J} 1.1$ on the total indigenous population, the counterselection method is expected to be also effective on putative indigenous transconjugants that are closely related to the donor. It may be assumed that strains that would most readily function as recipients to conjugation from $\mathrm{Cit} 7$ are the same strains that are sensitive to $\phi \mathrm{J} 1.1$. Plasmid transfer to these strains can therefore not be observed using this form of counterselection. It seems likely that a self-transmissible plasmid, at least via intermediate hosts, may reach any putative recipient where the plasmid is able to replicate. Spread to the rhizosphere and soil population via bacteria transiently present in the phyllosphere also seems likely. The results presented here show that large differences in gene transfer between habitats may occur. This aspect has to be considered in the context of risk assessment when using genetically modified micro-organisms.

\section{ACKNOWLEDGEMENTS}

The $P$. syringae pv. phaseolicola bacteriophage $\phi J 1$ was kindly provided by Jarkko Hantula, at the Department of Genetics, University of Helsinki. MIS whole cell fatty acid analysis by gas chromatography was made by Riitta Boeck, Department of Applied Chemistry and Microbiology, University of Helsinki. This work was supported by the Academy of Finland and the $\mathrm{Maj}$ and Tor Nessling-foundation.

\section{REFERENCES}

Andrews, J. H. (1992). Biological control in the phyllosphere. Annu Rev Phytopatbol 30, 603-635.

Bamford, D. H. \& Palva, E.T. (1980). Structure of the lipidcontaining bacteriophage $\phi 6$ : disruption by triton X-100 treatment. Biochim Biophys Acta 601, 245-259.

Bender, C. L. \& Cooksey, D. A. (1986). Indigenous plasmids in Pseudomonas syringae $\mathrm{pv}$. tomato: conjugative transfer and role in copper resistance. $J$ Bacteriol 165, 534-541.

Bradley, D. E., Taylor, D. E. \& Cohen, D. R. (1980). Specification of surface mating systems among conjugative drug resistance plasmids in Escherichia coli K-12. J Bacteriol 143, 1466-1470.

Burkardt, H. J., Riess, G. \& Puhler, A. (1979). Relationship of group P1 plasmids revealed by hetroduplex experiments; RP1, RP4, R68 and RK2 are identical. J Gen Microbiol 144, 341-348.

Datta, N., Hedges, R. W., Shaw, E. J., Sykes, R. B. \& Richmond, M. H. (1971). Properties of an $R$ factor from Pseudomonas aeruginosa. $J$ Bacteriol 108, 1244-1249.

van Elsas, J. D., Trevors, J. T. \& Starodub, M. E. (1988). Bacterial conjugation between pseudomonads in the rhizosphere of wheat. FEMS Microbiol Ecol 53, 299-306.

Grinsted, J., Sanders, J. R., Ingram, L. C., Sykes, R. B. \& Richmond, M. H. (1972). Properties of an $R$ factor which orginated in Pseudomonas aeruginosa 1822. J Bacteriol 110, 529-537.

Gordon, D. M. (1992). Rate of transfer among Escherichia coli strains from natural populations. J Gen Microbiol 138, 17-21.

Henschke, R. B. \& Schmidt, F. J. (1990). Use of wide host range promoters to monitor the fate of recombinant DNA in soil. In Bacterial Genetics in the Environment, pp. 200-206. Edited by J. C. Fry \& M. J. Day. London: Chapman \& Hall.

Hirano, S. S. \& Upper, C. D. (1991). Bacterial community dynamics. In Microbial Ecology of Leaves, pp. 271-294. Edited by J. H. Andrews \& S. S. Hirano. New York: Springer-Verlag.

Juniper, B. E. (1991). The leaf from the inside to the outside: A microbe's perspective. In Microbial Ecology of Leaves, pp. 21-42. Edited by J. H. Andrews \& S. S. Hirano. New York: SpringerVerlag.

King, E. O., Ward, M. K. \& Raney, D. E. (1954). Two simple media for the demonstration of pyocyanin and fluorescein. $J$ Lab Clin Med 44, 301-307. 
Klingmuller, W. (1991). Plasmid transfer in natural soil: a case study with nitrogen-fixing Enterobacter. FEMS Microbiol Ecol 85, 107-116.

Lacy, G. H., \& Leary, J. V. (1975). Transfer of antibiotic resistance plasmid PR1 into Pseudomonas glycinea and Pseudomonas phaseolicola in vitro and in planta. J Gen Microbiol 88, 49-57.

Lacy, G. H., Stromberg, V. K. \& Cannon, N. P. (1984). Erwinia amylovora mutants and in planta-derived transconjugants resistant to oxytetracycline. Can J Plant Pathol 6, 33-39.

Leben, C. (1988). Relative humidity and the survival of epiphytic bacteria with buds and leaves of cucumber plants. Pbytopathol 78, 179-185.

Lilley, A. K., Fry, J. C., Day, M. J. \& Bailey, M. J. (1994). In situ transfer of an exogenously isolated plasmid between Pseudomonas spp. in sugar beet rhizosphere. Microbiol 140, 27-33.

Lindow, S. E. (1991). Determinants of epiphytic fitness in bacteria. In Microbial Ecology of Leaves, pp. 295-314. Edited by J. H. Andrews \& S. S. Hirano. New York: Springer-Verlag.

Lindow, S. E. (1992). Environmental release of pseudomonads: potential benefits and risks. In Pseudomonas: Molecular Biology and Biotechnology, pp. 399-407. Edited by E. Galli, S. Silver \& B. Witholt. Washington, DC: American Society for Microbiology.

Lindow, S. E. (1993). Novel method for identifying bacterial mutants with reduced epiphytic fitness. Appl Environ Microbiol 59, 1586-1592.

Lindow, S. E., Clark, E. \& Wilson, M. (1992). Chromosomal insertion of $x y l E$ in Pseudomonas syringae as identifiable markers for ecological studies (abstract). Phytopathol 82, 1179.

Loper, J. E. \& Lindow, S. E. (1987). Lack of evidence for in situ fluorescent pigment production by Pseudomonas syringae pv. syringae on bean leaf surfaces. Pbytopathol 77, 1449-1454.

de Lorenzo, V., Herrero, M., Jakubzik, U. \& Timmis, K. (1990). Mini-Tn 5 transposon derivatives for insertion mutagenesis, promoter probing, and chromosomal insertion of cloned DNA in Gram-negative Eubacteria. J Bacteriol 172, 6568-6572.

Manceau, C., Gardan, L. \& Devaux, M. (1986). Dynamics of RP4 plasmid transfer between Xanthomonas campestris pv. corylina and Erwinia herbicola in hazelnut tissues, in planta. Can J Microbiol 32, 835-841.

McClure, N. C., Fry, J. C. \& Weightman, A. J. (1990). Gene transfer in activated sludge. In Bacterial Genetics in Natural Environments, pp. 111-129. Edited by J. C. Fry \& M. J. Day. London: Chapman \& Hall.

Miller, J. H. (1972). Experiments in Molecular Genetics. Cold Spring Harbor, NY: Cold Spring Harbor Laboratory.

Miller, I. \& Berger, T. (1985). Bacterial identification by gas chromatography of whole cell fatty acids. Hewlett Packard $A p$ plication Note 228-41.

Mukopadhyay, P., Mukopadhyay, M. \& Mills, D. (1990). Construction of a stable shuttle vector for high-frequency transformation in Pseudomonas syringae pv. syringae. J Bacteriol 172, $477-480$.

Olsen, R. H. \& Shipley, P. (1972). Host range and properties of the Pseudomonas aeruginosa R factor R1822. J Bacteriol 113, 772-780.

Orser, C., Staskawicz, B. J., Panopoulos, N. J., Dahlbeck, D. \& Lindow, S. E. (1985). Cloning and expression of bacterial ice nucleation genes in Escherichia coli. J Bacteriol 164, 359-366.

Powell, B. J., Purdy, K. J., Thompson, I. P. \& Bailey, M. J. (1993). Demonstration of $\mathrm{tra}^{+}$plasmid activity in bacteria indigenous to the phyllosphere of sugar beet; gene transfer to a recombinant pseudomonad. FEMS Microbiol Ecol 12, 195-206.

Romantschuk, M., Nurmiaho-Lassila, E.-L., Roine, E. \& Suoniemi, A. (1993). Pilus-mediated adsorption of Pseudomonas syringae to the surface of host and non-host plant leaves. $J$ Gen Microbiol 139, 2251-2260.

Sambrook, J., Fritsch, E. F. \& Maniatis, T. (1989). Molecular Cloning: a Laboratory Manual. Cold Spring Harbor, NY: Cold Spring Harbor Laboratory.

Schmidt, F. R. J., Rosien, J. \& Brokamp, A. (1990). The role of soil bacteria in risk assessment analysis. In Bacterial Genetics in Natural Environments, pp. 207-215. Edited by J. C. Fry \& M. J. Day. London: Chapman \& Hall.

Smets, B. F., Rittmann, B. E. \& Stahl, D. A. (1993). The specific growth rate of Pseudomonas putida PAW1 influences the conjugal transfer rate of the TOL plasmid. Appl Environ Microbiol 59, 3430-3437.

Smit, E. \& van Elsas, J. D. (1990). Determination of plasmid transfer frequency in soil: consequences of bacterial mating on selective agar media. Curr Microbiol 21, 151-157.

Smit, E., van Elsas, J. D., van Veen, J. A. \& de Vos, W. M. (1991). Detection of plasmid transfer from Pseudomonas fluorescens to indigenous bacteria in soil by using bacteriophage $\phi \mathrm{R} 2 \mathrm{f}$ for donor counterselection. Appl Environ Microbiol 57, 3482-3488.

Suoniemi, A., Björklof, K., Haahtela, K. \& Romantschuk, M. (1995). The pilus of Pseudomonas syringae pathovar syringae enhances initiation of bacterial epiphytic colonization of bean. Microbiology 141, 497-503.

Sörensen, S. J. (1993). Transfer of plasmid RP4 from Escherichia coli K-12 to indigenous bacteria of seawater. Microb Releases 2, 135-141.

Tiedje, J. M., Colwell, R. K., Grossman, Y. L., Hodson, R. E., Lenski, R. E., Mack, R. N. \& Regal, P. J. (1989). The planned introduction of genetically engineered organisms: ecological considerations and recommendations. Ecology 70, 298-315.

Top, E., Mergeay, M., Springael, D. \& Verstraete, W. (1990). Gene escape model: Transfer of heavy metal resistance gene from Escherichia coli to Alcaligenes eutrophus on agar plates and in soil samples. Appl Environ Microbiol 56, 2471-2479.

Tu, J., Wang, H.-R., Chou, H.-C. \& Tu, C. Y.-L. (1989). Mutation(s) necessary for the residence of RP4 in Xantbomonas campestris pv. citri. Curr Microbiol 19, 217-222.

Tukey, H. B., Jr, Wittwer, S. H. \& Tukey, H. B. (1957). Leaching of carbohydrates from plant foliage as related to light intensity. Science 126, 120-121.

Tukey, H. B., Jr (1970). The leaching of substances from plants. Annu Rev Plant Pbysiol 21, 305-324.

Vidaver, A. K., Koski, R. K. \& Van Etten, J. L. (1973). Bacteriophage $\phi 6$ : a lipid-containing virus of Pseudomonas phaseolicola. $J$ Virol 11, 799-805.

Wilson, M. \& Lindow, S. E. (1993). Population dynamics of Pseudomonas syringae A506 in pear flowers following inoculation in relation to strategies for biological control of fire blight and frost injury. Acta Hort 338, 331-332.

Worsey, M. J., Franklin, F. C. H. \& Williams, P. A. (1978). Regulation of the degradative pathway enzymes coded for by the TOL plasmid (pWWO) from Pseudomonas putida mt-2. J Bacteriol 134, 757-764.

Received 14 March 1995; revised 2 June 1995; accepted 15 June 1995. 